
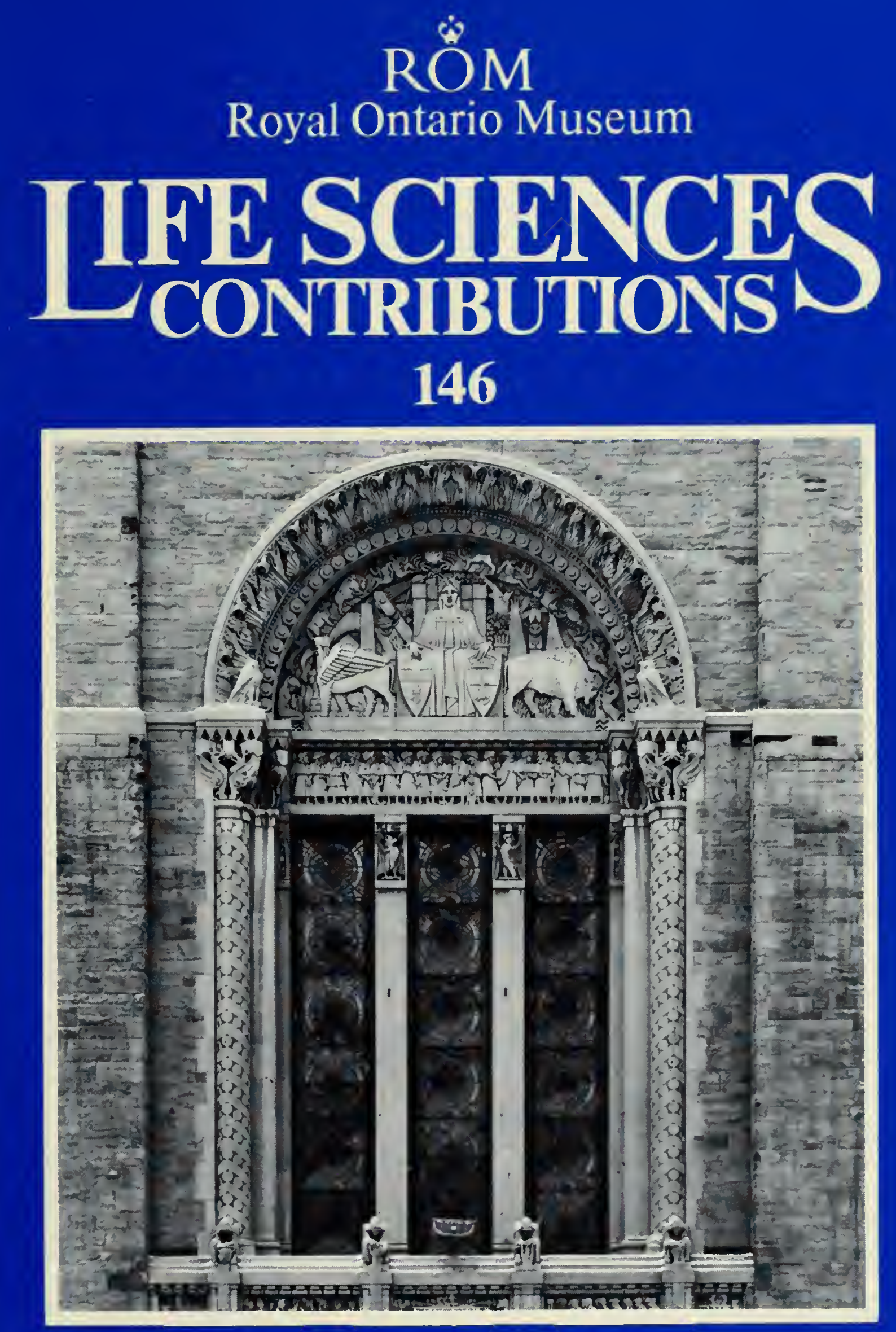

Stipatocrinus, a New and Unusual Camerate Crinoid from the Lower Silurian of Western New York

James D. Eckert and Carlton E. Brett 


\section{ROYAL ONTARIO MUSEUM LIFE SCIENCES PUBLICATIONS INSTRUCTIONS TO AUTHORS}

Authors should prepare their manuscripts carefully according to the following instructions; failure to do so will result in the manuscript's being returned to the author for revision. All manuscripts are considered on the understanding that they are not currently offered for publication elsewhere.

1. General Papers for publication are accepted from ROM staff members and research associates, and from researchers reporting on work done with ROM collections. Monographs on the flora and/or fauna of Ontario may be considered for publication by authors not affiliated with the ROM. Financial contributions towards publication will be welcome. Authors are expected to write clearly and concisely and to omit any material not essential for an understanding of the main theme of the paper.

2. Format Manuscripts (including captions, synonymies, literature cited, and tables) should be typed with double space on 11 " $\times 8 \frac{1}{2}$ " paper with a $1 \frac{112}{2}$ margin on all sides. Three xerox copies should be submitted to the Senior Editor of the Editorial Board; the original should be retained by the author(s). The submission should include a separate sheet giving the author(s) names and affiliations, the title of the publication, the series for which it is submitted, the number of typed pages, the number of tables, and the number of plates or figures. Manuscripts should normally be organized in the following order: Contents, Abstract, Introduction, Materials and Methods, Results, Discussion, Conclusions, Summary (if manuscript is long), Acknowledgements, Appendices, and Literature Cited. Authors are encouraged to include foreign-language translations of the Summary, if appropriate. Main headings should be centred; subheadings should be left-justified to the text margin. The first line of the first paragraph in each new section should not be indented. Literature citations in the text should be in the form "Jones (1972)" or "(Jones, 1972)" or "(Smith, 1960:71-79, fig. 17)".

3. Standard Sources The primary authority on questions of format and style is Guide to Authors, available from ROM Publication Services. For matters not covered in the Guide, consult CBE Style Manual (Fifth Edition). Other standard sources are as follows: for
English spelling, The Concise Oxford Dictionary; for Canadian place names and coordinates, Canada Gazetteer Atlas; for the spelling of geographic names, The Times Atlas.

4. Abstract All papers must be preceded by a short, factual abstract, about one per cent of the text in length. The abstract may be followed by four to six key words in parentheses.

5. Taxonomy The name of a taxon should be given in full in headings, at the beginnings of paragraphs, and at its first occurrence in the text. Give the authority and date, if appropriate, with the first mention of each taxon, but not thereafter. Taxonomic papers, particularly synonymies, should follow the layout in Life Sciences Contributions beginning with No. 136. International Codes of Biological Nomenclature must be followed.

6. Literature Cited A complete list of references, in alphabetical order of authors, must be given at the end of the paper. When two or more works of one author are cited, they should be listed chronologically. The names of journals should not be abbreviated. For correct bibliographic form, see Life Sciences Contributions beginning with No. 136.

7. Tables All tables should be typed on separate sheets and numbered consecutively in arabic numerals in the order of their first mention in the text. Mark the location of each table in the margin of the text.

8. Plates, Figures, and Text-figures Illustrations may be designated according to the conventions of the author's discipline; in some disciplines grouped photographs of scientific subject matter are commonly termed Plates, while line drawings and locality and other illustrations that occupy a full page or less are Text-figures. Usage must be consistent throughout the paper. A full-page illustration for a Contribution, with its caption, should be sized to fit an area of $17.3 \times$ $22.75 \mathrm{~cm}$; for Occasional Papers, the area is $14.1 \times$ $21.2 \mathrm{~cm}$. If captions are lengthy, they may be placed on the facing page. A scale or magnification factor should be included. Authors are reminded that when illustrations are reduced magnification factors will change, and that they are responsible for the conversion. For details, see Guide to Authors. 


\title{
Stipatocrinus, a New and Unusual Camerate Crinoid from the Lower Silurian of Western New York
}

\author{
James D. Eckert \\ and \\ Carlton E. Brett
}


The Royal Ontario Museum publishes three series in the Life Sciences: CONTRIBUTIONS: a numbered series of original scientific publications.

OCCASIONAL PAPERS: a numbered series of original scientific publications, primarily short and of taxonomic significance.

MISCELLANEOUS PUBLICATIONS: an unnumbered series on a variety of subjects.

All manuscripts considered for publication are subject to the scrutiny and editorial policies of the Life Sciences Editorial Board, and to independent refereeing by two or more persons, other than Museum staff, who are authorities in the particular field involved.

\section{LIFE SCIENCES EDITORIAL BOARD}

Senior Editor: E. J. Crossman

Editor: Judith L. Eger

Editor: C. Darling

External Editor: C. S. Churcher

Manuscript Editor: Judith L. Eger

Production Editor: Barbara lbronyi

James D. Eckert completed his M.Sc. studies in the Department of Geology at the University of Toronto in 1981. He is currently continuing graduate studies in the Department of Geological Sciences, University of Rochester, Rochester, New York.

Carlton E. Brett is associate professor in the Department of Geological Sciences, University of Rochester.

\section{Canadian Cataloguing in Publication Data}

Eckert, James D., 1952-

Stipatocrinus, a new and unusual camerate crinoid from the Lower Silurian of western New York

(Life sciences contributions ; 146)

Bibliography: $\mathrm{p}$.

ISBN 0-88854-336-0

1. Crinoidea, Fossil. 2. Paleontology - New York

(State) - Ordovician. 3. Paleontology - New York

(State). I. Brett, Carlton Elliot. II. Royal

Ontario Museum. III. Title. IV. Series.

QE782.E24 $1987 \quad 563^{\prime} .9 I^{\prime} 097479 \quad$ C87-094782-6

Publication Date: 15 November 1987

ISBN 0-88854-336-0

ISSN 0384-8159

(C) Royal Ontario Museum, 1987

100 Queen's Park, Toronto, Canada, M5S 2C6

PRINTED AND BOUND IN CANADA AT THE ALGER PRESS 


\title{
Stipatocrinus, a New and Unusual Camerate Crinoid from the Lower Silurian of Western New York
}

\begin{abstract}
Stipatocrinus hulveri gen. et sp. nov. is described from the Upper Llandoverian Reynales Formation of western New York. Diagnostic characters of this unusual camerate crinoid include a peculiar cup in which the lowest circlet, consisting of two large and two small plates designated as basals divided by sutures passing through the AE-interray and Cray, possesses a combination of infrabasal, basal, and radial features. Unique t-shaped radials bridge interrays consisting of numerous small interbrachials irregular in shape and arrangement. Stipatocrinus probably represents an archaic, previously unrecognized lineage of camerate crinoids that persisted into the Silurian but became extinct in the late Llandoverian. Thinly plated, flexible interrays of Stipatocrinus reduced metabolic cost of skeletal growth and possibly aided in respiration.
\end{abstract}

\section{Introduction}

Crinoids are poorly represented in Lower Silurian (Llandoverian) strata of eastern North America. This interval is critical to understanding the evolution of the class, for it followed major Late Ordovician extinctions that decimated crinoids and other groups of marine invertebrates and preceded major taxonomic radiation and restructuring of crinoid assemblages in the Late Silurian (Wenlockian). One might predict, therefore, that Llandoverian crinoid assemblages would comprise transitional forms, including ancestral stocks of certain of the major Wenlockian clades. Indeed, such precursor taxa have been reported from the Hopkinton Dolomite (late Llandoverian, $\mathrm{C}_{3}-\mathrm{C}_{6}$ ) in lowa (Witzke, Frest, and Strimple, 1979; Witzke and Strimple, 1981), and a slightly older fauna is known from the Brassfield Formation of Ohio (Ausich, 1985, 1986a, 1986b) in strata considered to be of late Llandoverian $\left(\mathrm{C}_{1}-\mathrm{C}_{2}\right)$ age (Berry and Boucot, 1970). Potential ancestors of Wenlockian crinoids also occur in the Cataract Group of Ontario (Eckert, 1984) and in the lower Clinton Group (middle to late Llandoverian, $\mathrm{B}_{3}-\mathrm{C}_{4}$ ) of the northern Appalachian Basin in New York State (Eckert, in prep.). However, Early Silurian crinoid assemblages of Ontario and New York State are also distinctly Ordovician in aspect and characterized by persistence of primitive lineages. For example, Ptychocrinus medinensis, a species closely related to the Late Ordovician crinoid $P$. splendens, is locally abundant in the Power Glen Formation (early Llandoverian, $\mathrm{A}_{2}-\mathrm{A}_{3}$ ) of New York and the Cabot Head Formation of Ontario (Brett, 1978; Eckert, 1984). The Reynales Formation contains undescribed crinoids very similar to the Middle Ordovician crinoid Tornatilicrinus from the Lebanon Limestone of Tennessee. Stipatocrinus hulveri gen. et sp. nov. is also inferred to represent a primitive but persistent Ordovician lineage. These taxa appear to represent relict lineages that escaped Ashgillian extinction. Stipatocrinus hulveri formed monotypic, high-density assemblages, suggesting that it may have acted as an opportunistic species that thrived in physically stressed, uncrowded environments such as existed in the Early Silurian of the northern Appalachian Basin. These environments may have provided a refuge for primitive holdover taxa that became extinct or were displaced coincidentally with an invasion of diverse Wenlockian echinoderm associations that may have evolved in the North American midcontinent (Witzke, Frest, and Strimple, 1979) or in presently unknown areas.

\section{Occurrence and Stratigraphy}

In 1983, while studying Early Silurian brachiopod communities in western New York, Michacl Hulver of the University of Chicago discovered dolostone slabs covered with long crinoid stems from talus in the eastern side of the gorge of the Genesee River at Rochester, New York
(Text-Figs. 1, 2). Subsequent investigation by Brett resulted in discovery of numerous nearly complete individuals of Stipatocrinus hulveri gen. et sp. nov. at this site, $0.3 \mathrm{~km}$ north of the lower falls of the Genesee River and 10 to $40 \mathrm{~m}$ east of the Rochester Gas and Electric aceess 


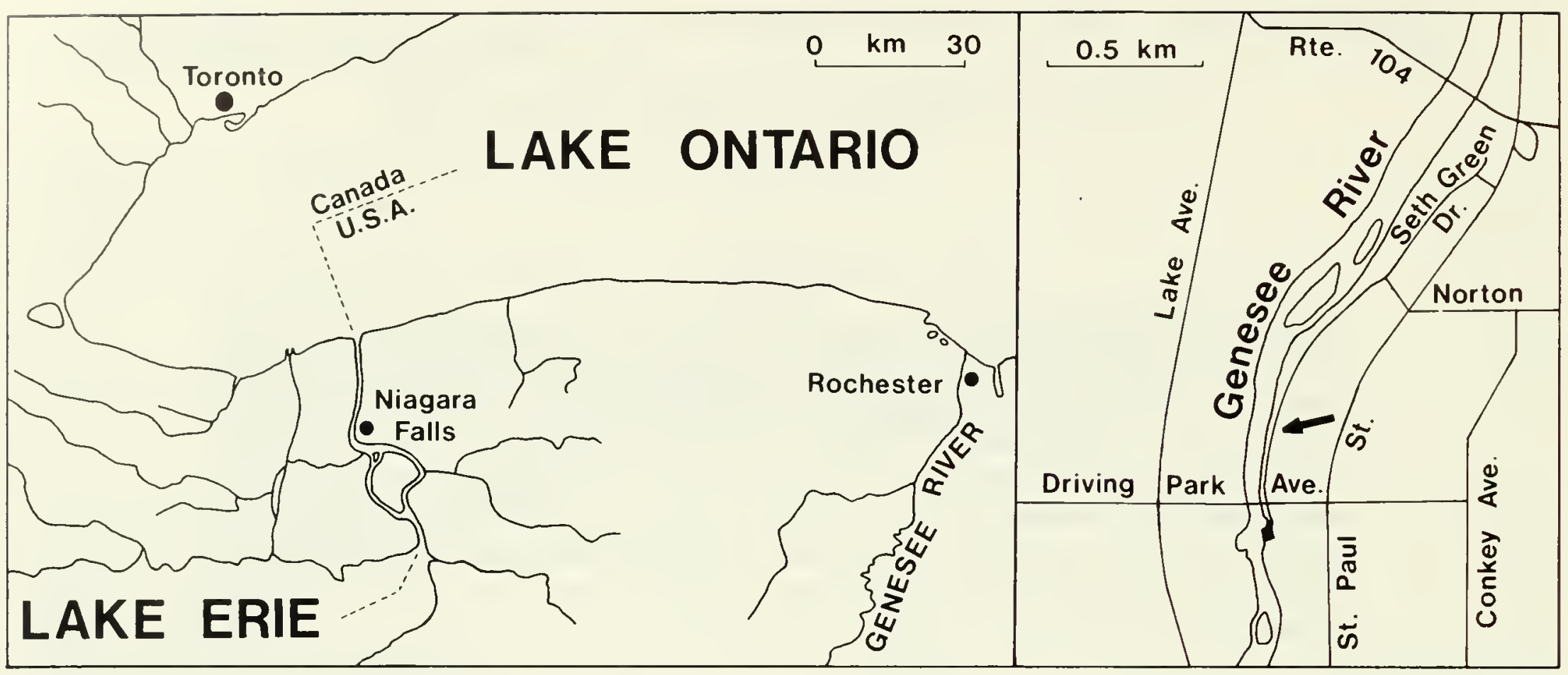

TEXT-FIG. I. Locality map of southwestern Ontario and western New York State. Arrow in inset at right indicates occurrence of Stipatocrimus hulveri gen. et sp. nov.

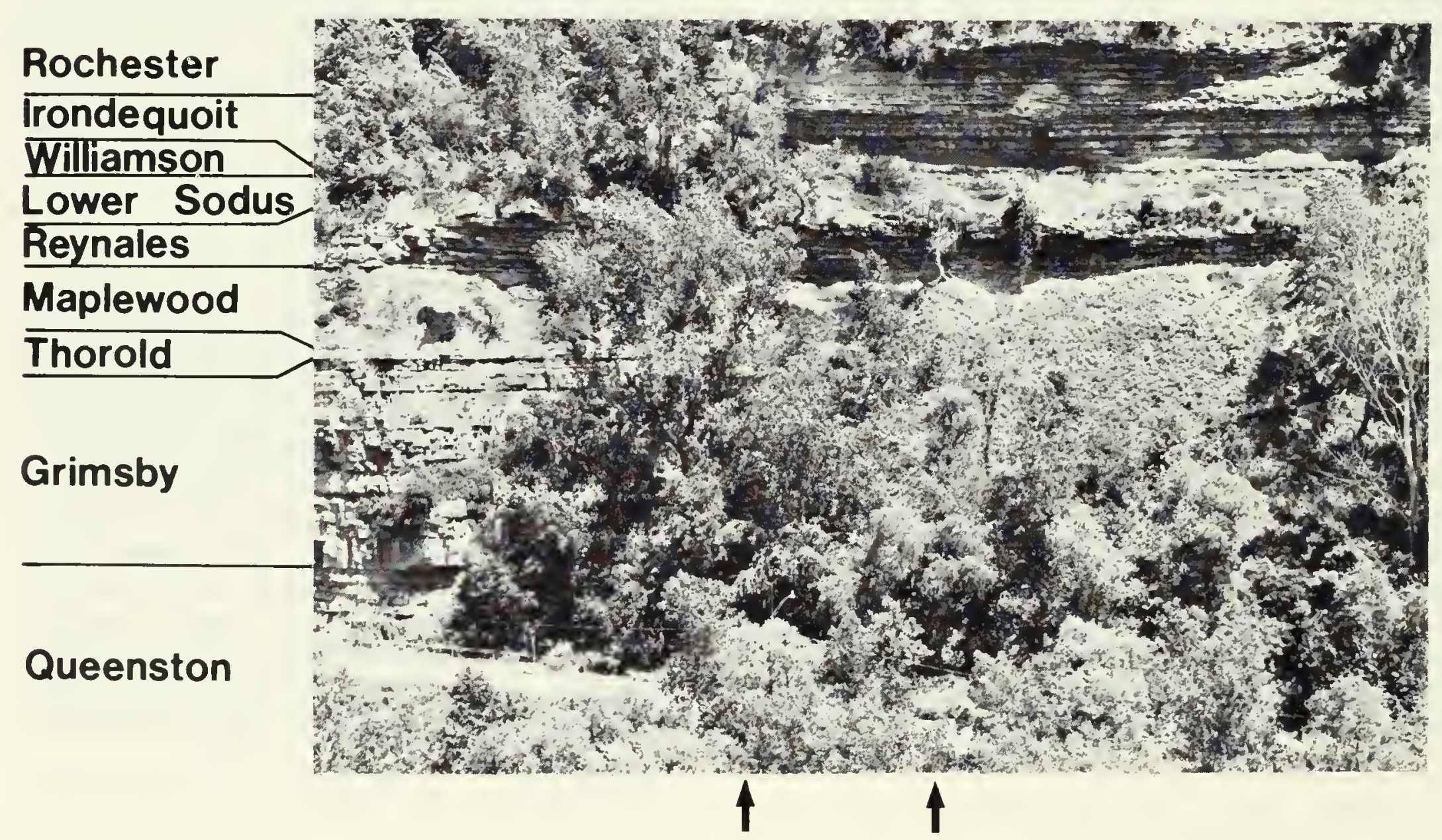

Text-FIg. 2. Upper Ordovician Queenston Formation and Silurian formations exposed in eastern side of gorge of Genesee River at Rochester, New York. Vertical section is approximately $50 \mathrm{~m}$. Slabs bearing Stipatocrimus hulveri gen. et sp. nov. were found on talus slope between access road and Reynales Formation exposed in cliff. Arrows indicate lateral extent of occurrence. 
road south of Seth Green Drive, Rochester, Monroe County, New York (United States Geological Survey, Rochester West 7.5' Quadrangle).

Crinoid-bearing slabs appear to comprise parts of a large rockfall from the Wallington Member of the Reynales Formation, exposed in the cliff above the talus (Text-Fig. 2). Laminated calcisiltite containing crinoids closely resembles that found interbedded with green shales near the base of the Wallington Member. Crinoid columns and distinctive t-shaped radials were obtained in situ from the lowest metre of this member, which probably represents the horizon from which the study material was eroded.

The Reynales Formation, also known as the Reynales Limestone, consists of complex, time-trangressive, dominantly carbonate strata extending from the Niagara area eastwards to near Wolcott, New York, where it grades laterally into the Bear Creek Shale. The Wallington Member (Fisher, 1960) is the uppermost unit of the Reynales Formation in the Rochester area. Approximately $4 \mathrm{~m}$ thick in the Genesee Gorge, the Wallington consists of thin- to medium-bedded, light grey, cherty, dolomitic limestone and dolostone with greenish-grey shale partings. Crosslamination with a maximum amplitude of $2 \mathrm{~cm}$ occurs in calcisiltite (pelletal grainstone beds). Several horizons of fossiliferous packstone and grainstone within the Wallington contain abundant specimens of the brachiopods Pentamerus oblongus and Eocoelia hemispherica. On the basis of these brachiopods, the Wallington was considered to be of late Llandoverian $\left(C_{4}\right)$ age (Berry and Boucot, 1970). However, further consideration of brachiopod and conodont biostratigraphy led Rickard (1975) to propose an earlier $\left(\mathrm{C}_{2}\right)$ age.

\title{
Materials and Methods
}

Most specimens of Stipatocrinus hulveri gen. et sp. nov. are embedded in a hard, dolomitic calcisiltite and proved difficult to prepare. Attempts to remove matrix, using sodium bicarbonate in an airbrasive machine, were not successful. Dolomite powder proved to be an effective abrasive but readily damaged the thin plates of these crinoids. Fortunately a few specimens, including the holotype, are embedded in a softer, slightly argillaceous matrix and were prepared using needles and airbrasion with little damage.
Immersion of specimens in ethanol facilitated morphologic study. Text-Figures 5,6, and 7 were prepared by tracing over photographs. Plate dimensions were measured using vernier calipers; orientations of these plates are given in Table 1.

All study material is deposited in the collections of the Department of Invertebrate Palaeontology, Royal Ontario Museum (ROM) in Toronto, Ontario, Canada.

\section{Systematic Palaeontology}

\author{
Class Crinoidea Miller, 1821 \\ Subclass Camerata Wachsmuth and Springer, 1885 \\ ?Order Monobathrida Moore and Laudon, 1943 \\ Superfamily Stipatocrinacea superfam. nov.
}

\section{DIAGNOSIS}

Lowest circlet in cup consisting of four plates (basals?); two large plates adjacent to one another along C-ray suture and two small plates directly in line with A- and E-ray radials. This circlet divided by sutures in AB-, DE-, and EA-interrays. Radials and fixed brachials narrow, elongate, raised. Primanal and anitaxis absent. Interbrachials small, exceptionally numerous, irregular in shape and arrangement.

Family Stipatocrinidae fam. nov.

\section{DIAGNOSIS}

Characters of superfamily.

Stipatocrinus gen. nov.

\author{
TYPE SPECIES \\ Stipatocrinus hulveri sp. nov.
}

\section{ETYMOLOGY}

From the Latin stipatus-crowded-in reference to the numerous interbrachials crowded together in the interrays. and from the Greek krinon-lily.

\section{DIAGNOSIS}

Monotypic genus of Stipatocrinidae with narrow conical cup and depressed interrays. Radials t-shaped, bridging interrays. Primibrachials two in each ray. clongate, straight sided, grooved ventrally. Fixed secundibrachials four to 


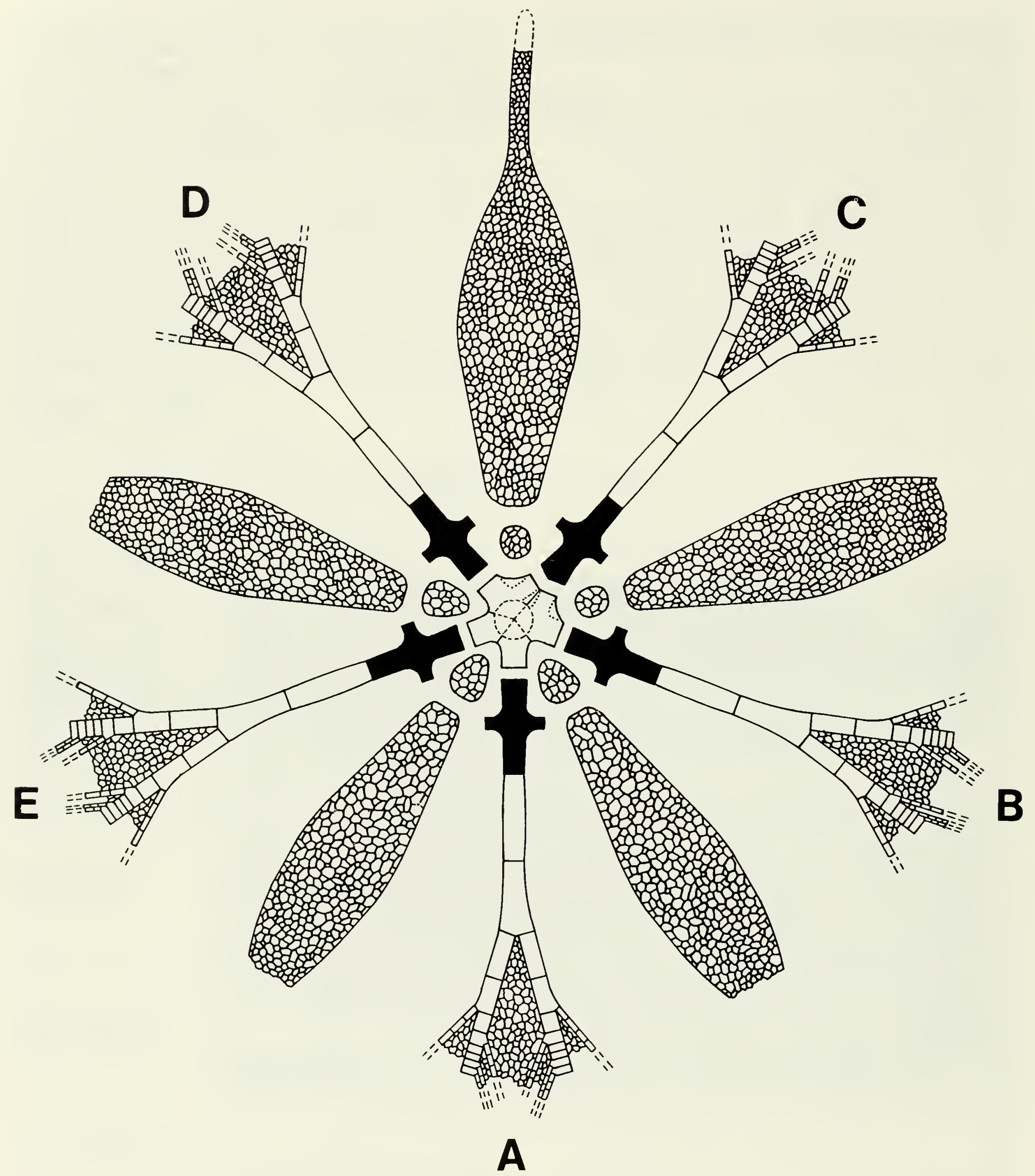

Text-Fig. 3. Plate diagram of Stipatocrinus hulveri gen. et sp. nov. Note peculiar configuration of proximal circlet, divided into bilaterally symmetrical halves by sutures in AE-interray and C-ray. The t-shaped radials (black) enclose suboval interbrachial areas and are smaller in BC-and CD-interrays than in remaining interrays. 
six in each ray branch. Fixed pinnule borne by second secundibrachial. Interbrachials smooth, without ornamentation. Narrow cylindrical anal tube eccentrically located on tegmen. Arms ten, pinnulate; brachials in immature biserial arrangement. Column transversely circular.

\section{DISCUSSION}

There is little doubt that Stipatocrinus gen. nov. belongs to the subclass Camerata in view of its densely pinnulate arms, fixed ray series, fixed pinnules, and numerous interbrachials. However, below this level, classification becomes difficult. It is not clear whether Stipatocrinus should be classified among the Monobathrida or the Diplobathrida, or in a separate order altogether, because the peculiar plate configuration of the base of the cup in this crinoid renders plate homologies obscure. The problem is conpounded, for the column of Stipatocrinus is neither pentameric nor pentagonal, but cylindrical with a round lumen. Hence, this column does not provide any indication of orientation of thecal plates relative to the entoneural system, as suggested by the "Law of Wachsmuth and Springer" (Warn, 1975).

Even the location of radials in Stipatocrinus is some what problematic. The A- and E-rays are each supported by a single uninterrupted row of plates beginning in the lowest circlet of the cup (Text-Fig. 3). Thus, plates of this circlet in the A- and E-rays could be considered to be radials. However, if this interpretation is followed, the radials of these rays would lie immediately above the stem facet, a feature unknown in all other crinoids. In the B-, C-, and D-rays the lowest plates of the rays are t-shaped and situated within the second circlet of plates (Text-Fig. 3). These $\mathrm{t}$-shaped plates are relatively narrow, as in fixed brachials, and are even grooved ventrally (Pl. 1, figs. 16,20). However, they are differentiated from all other cup plates by their lateral processes, and they form a distinctive circlet. We feel fairly confident in designating plates of the second circlet as radials because a t-shaped plate of the C-ray overlies a suture between plates of the lowest circlet. This plate is therefore in typical radial position. Furthermore, the strong differentiation of these plates is also suggestive of radials. In other primitive camerate crinoids, including reteocrinids and xenocrinids, the radials are always markedly separate from other adjacent plates (Brower, pers. comm., 1986).

Configuration of the lowest circlet of cup plates in Stipatocrinus is unique among camerate crinoids, both in terms of the shapes and relative sizes of these plates and, most notably, in their orientation with respect to the radials. The lowest circlet combines features of inlrabasals, basals, and radials. Three of four sutures dividing this circlet are interradial (AB-, DE-, and EA-interrays), a characteristic of infrabasals; the fourth suture is directly below the C-ray radial as it would be in a normal basal
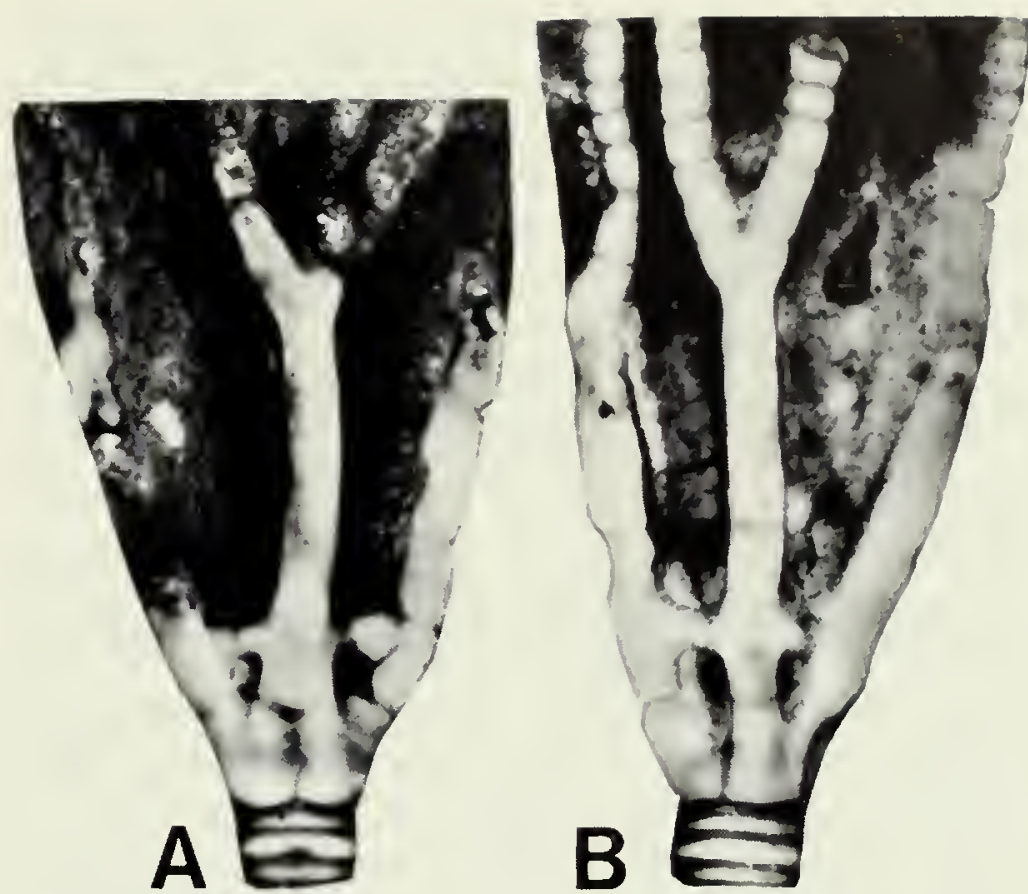

TeXT-Fig. 4. Stipatocrinus hulveri gen. et sp. nov. Specimens immersed in ethanol.

A. Individual centred on C-ray. Proximal circlet is divided by suture in $\mathrm{C}$-ray but not in $\mathrm{BC}$ - or $\mathrm{CD}$-interrays. Aborally directed bifurcation of C-ray ridge continues on basals. Small suboval interbrachial areas in BC- and CD-interrays, bounded above by $t$-shaped radials, are of similar size. Interbrachials. underlain by black integument, are poorly preserved. Paratype ROM 44309a, × 4.0.

B. Individual centred on D-ray. Proximal circlet is divided by suture in C-ray and DE-interray but not in CD-interray. Suboval interbrachial area in DE-interray, bounded above by t-shaped radials, is smaller than adjacent area in CD-interray. Interbrachials are well preserved in this specimen, and proximal portion of anal tube is visible. Paratype Rom $44309 \mathrm{~b}, \times 4.0$.

circlet (Text-Figs. 3, 4A,B). Furthermore, two plates in the lowest circlet resemble radials because they are directly in line with and support the A- and E-rays.

An unusual and interesting feature of Stipatocrinus is that the plates of the lowest circlet are dissimilar in size and shape with respect to each other. Two plates of this circlet, directly in line with the A- and E-rays, are fivesided and considerably smaller (narrower) than the larger six-sided plates that they adjoin laterally (Text-Fig. 3). Pairing of each larger plate with a smaller one divides the lowest circlet into bilaterally symmetrical halves, each with two plates, about a sutural plane passing through the AEinterray and C-ray. To our knowledge, no other camerate crinoids, including xenocrinids, possess a basal circlet with this symmetry.

We emphasize that the peculiar configuration of the lowest circlet of cup plates in Stipatocrinus is not an abnormality. Consistent orientations have been observed in all seven specimens that have been adequately prepared. Furthermore, plate organization appears well coordinated with raly ridge configuration. 
Homology of the lowest circlet of cup plates in Stipatocrinus is a problem. We have termed these plates basals because they comprise the only circlet of plates between the stem facet and inferred radial circlet. However, the proximal circlet resembles a typical basal circlet only at the C-ray suture, situated directly below the C-ray radial. An alternative interpretation is that the lowest circlet of plates in Stipatocrimus may be homologous with the infrabasals of dicyclic camerates, in which the sutures are invariably interradial in position. However, number and sutural configuration of plates in the lowest circlet of Stipatocrinus do not precisely conform to that of a normal camerate crinoid infrabasal circlet. Nearly all diplobathrans possess five equal infrabasals, although the Anthemocrinidae possess four. None of these crinoids has a suture in the C-ray position as in the Stipatocrimus base. Instead, sutures between infrabasals normally occur in the BC-and CD-interrays; such sutures are absent in Stipatocrimus (TextFigs. 3, 4A).

The origin of the unequal basals in Stipatocrimus is unclear. The infrabasal circlet of anthemocrinids, a family unrelated to Stipatocrinus, possesses a large plate presumably derived from fusion of two smaller plates. In contrast, Stipatocrinus possesses two large and two snall plates in the lowest circlet. The two large plates could have developed by lateral fusion of two pairs of plates in an infrabasal circlet that originally possessed six plates. However, this seems unlikely, for crinoids with six infrabasals are unknown. A more plausible explanation is that the two larger plates of Stipatocrints were derived in two different ways: one by fusion of two plates, the other by enlargement of a single plate, so that the sutural position migrated from an interradial to a radial position. This would imply an ancestral condition with five plates in the lowest circlet, for which no evidence exists.

If the lowest cup plates of Stipatocrinus are homologous with infrabasals, we are faced with the obvious problem of absence of a basal circlet. Most researchers have implied that a pseudomonocyclic condition results from loss of infrabasals (Warn, 1975; Ubaghs, 1978). For example, the inadunate genus locrimus could have evolved from Merocrinus by loss of infrabasals. Alternatively, certain monocyclic inadunates including Belemnocrinus may have evolved from dicyclic forms by loss of the basal circlet (McIntosh, 1979). The latter process may also have occurred in Stipatocrimus.

The interrays of Stipatocrinus are peculiar in several respects. Most notably, they are filled with an exceptional number of small ossicles, more than 400 plates in the CDinterray of the holotype specimen (ROM 44310a, Pl. 1, figs. 1,3). Moreover, these plates are irregular in size, shape, and arrangement and are unusually thin. Unlike the majority of camerate crinoids, Stipatocrimus has interrays without a well-developed gradient of progressively smaller plates distally. Finally, Stipatocrinus lacks a primanal and anitaxis but possesses a cylindrical anal tube composed of plates resembling interbrachials.

Moore and Laudon (1943) considered small, irregular, and numerous interbrachials to be a primitive character. Brower (1974a) believed this characteristic to be advanced in xenocrinids, crinoids with interray plating similar to Stipatocrinus and occurring stratigraphically above supposedly related camerates with fewer and larger interbrachials. However, this conclusion was based, in part, on a misinterpretation of the phylogeny of xenocrinids (Brower, pers. comm., 1986). Poorly known phylogenies of camerate crinoids do not prove that either of these conflicting theories is correct. However, we believe that ontogenetic patterns of growth in primitive pelmatozoans and biostratigraphic evidence lend support to the Moore and Laudon hypothesis.

Ontogeny of interbrachials in most camerate crinoids was closely integrated and coordinated with increase in size of the cup (Brower, 1974b). Originating near the periphery of the tegmen, interbrachials were derived from tegmen interambulacrals that were modified in size and shape, becoming regular polygons as they were gradually incorporated into interrays. Consequently, interrays of most camerate crinoids typically show a well-developed gradient of progressively smaller and more irregular interbrachials towards the tegmen. This gradient apparently evolved early in the history of camerates, first appearing in the Lower Ordovician crinoid Proxenocrimus.

Unlike that of most crinoids, ontogeny of interbrachials in Stipatocrinus and the Late Ordovician crinoid Xenocrinus was poorly coordinated and poorly integrated with overall growth of the cup. In these crinoids, interbrachials grew more slowly than other calyx plates, necessitating an intercalatory mode of growth (Brower, 1974a). As a consequence of this mode of growth, interbrachials in Stipatocrinus and Xenocrinus are irregular in shape and arrangement. Interbrachials could have been added anywhere within interrays of these crinoids. This pattern is especially well developed in Stipatocrinus, in which small interbrachials adjacent to larger interbrachials are scattered throughout interrays. Intercalation increased the number of interbrachials at a given level within the cup as this crinoid grew. New interbrachials were also added by incorporation of interambulacrals. Interbrachials in Stipatocrimus merge smoothly into the tegmen, indicating that tegmen plates were incorporated into interrays, unaccompanied by substantial modification in size or shape of these ossicles. Because of an intercalatory mode of growth, interrays of Stipatocrinus and Xenocrimus display a poorly developed gradient of progressively smaller plates distally.

The origin of camerate crinoids and their relationships to other groups of pelmatozoans is poorly known. However, biostratigraphic evidence indicates that primitive 
Cambrian pelmatozoans, including the probable crinoid Echmatocrinus, are characterized by thecae possessing a large number of plates irregular in shape and arrangement. Moreover, thecae of these echinoderms typically show a poorly developed gradient of progressively smaller plates distally, and these plates commonly merge into the tegmen with little differentiation. We suggest that similar features in Stipatocrinus represent primitive characters.

The calyces of Stipatocrinus and Xenocrinus are similar in that both possess large numbers of small irregular interbrachials. However, Xenocrinus has a well-developed anitaxial ridge, and configuration of the lowest circlet of plates in Stipatocrinus is unlike that of Xenocrimus. We conclude that similar morphology of interrays suggests simply that these crinoids belong to archaic lineages probably not closely related to each other. In fact, superficial similarity of these genera could be an example of convergent evolution, although this possibility seems doubtful. It implies repeated development of large numbers of small interbrachials from ancestors with larger regular interbrachials, which is contrary to evolutionary trends in camerate lineages of simplifying cup structure by reducing numbers of interbrachials or eliminating them altogether.

Even the assumption that Stipatocrinus is related to diplobathran camerates does not provide insight into the evolution of this genus. Gaurocrinus and Reteocrinus, both members of the Reteocrinidae, possess large numbers of irregular interbrachials as in Stiputocrinus. However, these crinoids have a primanal within the radial circlet and also possess a prominent, ridged anitaxis. Furthermore, Reteocrinus has divergent characters, including interinfrabasal gaps, spiculelike interbrachials, and apinnulate, branching arms. None of the more advanced diplobathrans is at all similar to Stipatocrinus. Thus, Stipatocrinus presently stands by itself. We follow convention in tentatively assigning this genus to the Monobathrida because only a single circlet of plates is situated below the radials. However, we also emphasize that the present monocyclic-dicyclic schism in classification of crinoids, discussed by Warn (1975), may obscure phylogenetic relationships. In fact, Stipatocrimus may belong to a sister group of the Diplobathrida. Discovery of additional genera related to Stipatocrinus may readily justify erection of a new order to encompass these unusual crinoids. We conclude that the several seemingly primitive features of Stipatocrinus suggest that it may have been a "living fossil" in late Llandoverian scas.

\section{Stipatocrinus hulveri sp. nov.}

Text-Figs. 1-8; Pl. 1, figs. 1-21; Pl. 2, figs. $1-12$

\section{TYPE MATERIAL,}

Numbered slabs containing approximately 75 calyces and crowns associated with numerous columnals and columns of this species are deposited in the collections of the Department of Invertebrate Palaeontology at the Royal Ontario Museum, catalogue numbers ROM 44309-44344. Figured specimens: holotype ROM $44310 a$; paratypes ROM $44309 a, b . d ; 44310 b-44323$.

\section{OCCURRENCE}

Reynales Formation, Wallington Mcmber, exposed in the gorge of the Genesee River, Rochester, New York.

\section{ETYMOLOGY}

The species is named in honour of Michael Hulver.

\section{DIAGNOSIS}

As for genus.

\section{DESCRIPTION}

Calyx steeply conical (height width $=1.5-1.7$ ), with highly elevated ray ridges and depressed interrays. CD-interray about 20 per cent wider than other interrays.

Four plates in lowest cup circlet, here designated as basals, possibly representing infrabasals. Proximal circlet comprising approximately 15 per cent of calyx height, divided by sutures in $\mathrm{AB}-$, DE-, and EA-interrays and in C-ray, undivided in $\mathrm{BC}$ - and $\mathrm{CD}$-interrays (Text-Figs. 3 , 4A,B; Pl. I, figs. 1 ,5,6,13-15). Basals two large and two small (Pl. 1. fig. 13). Basals directly underlying A-and E-ray radials five-sided, smaller (narrower) than larger sixsided basals occupying AB- through DE-interrays (TextFigs. 3, 4A. B. 7; Pl. I, figs. 5,6). Smaller basals elongate, widest just above stem facet (PI. 1, fig. 5). Larger basals expanding in width distally. Sutures passing through AEinterray and C-ray divide basal circlet into bilaterally symmetrical halves (Text-Fig. 3). In AB-, DE-, and EAinterrays basals meeting along straight suture for about one-third to one-half of basal height, diverging above forming concave margins of proximal interrays (Text-Fig. 3; Pl. 1, fig. 5). In BC- and CD-interrays these concave margins less pronounced, not extending as close to stem facet (Text-Figs. 3, 4A). Basals in A- and E-rays each with ridge continuing onto $\mathrm{A}$ - and $\mathrm{E}$-ray radials, respectively. Larger basals meeting directly below C-ray along straight suture for about 80 per cent of basal height, each possessing two adradially directed ridges. Pair of ridges divided by suture separating these basals merging upwards, forming single ridge on $\mathrm{C}$-ray radial (Text-Figs. 3, 4A).

Radials and higher fixed brachials grooved ventrally $(\mathrm{Pl}$. 1, figs. 16,17,20,21), extremely narrow, lorming highly elevated ray ridges extending full width of brachials (TextFigs. 3, 4A, B, 8; Pl. 2, figs. I-5). Radials t-shaped (height maximum width $=1.6-1.8)$. Each radial bisected near midpoint by pair of short, narrow, laterally directed projections (Text-Figs. 3, 4A. B; Pl. 1, figs. 5,20). Projections 
forming ridges lower in height than ray ridges, crossing proximal interray areas, narrowly joining radials together.

First primibrachials rectangular, highly elongate (height width $=3.0-5.0$ ), straight-sided. Second primibrachials Y-shaped (height/width $=1.4-1.6)$, axillary (Pl. 1, fig. $10)$. Each ray bifurcating near centre of second primibrachial, forming two straight ray ridge scgments continuing upwards towards arms. First secundibrachials rectangular (height/width $=1.5-1.9$ ), each bearing a stout fixed pinnule bounded by interprimibrachials (Pl. I, figs. 1,4). Sccond secundibrachials equidimensional (height/width $=1.0$ ). Succeeding fixed secundibrachials rectangular, wider than high (height/width $=0.6-0.8$ ). Arms free beyond third to seventh secundibrachial.

Interrays filled with exceptionally numcrous interbrachials (more than 400 ossicles in CD-interray of holotype specimen, ROM 44310a; Pl. I, fig. 1). Interrays of smaller individuals with fewer plates (Pl. 2, figs. 10,11). Interbrachials immediately above basals enclosed in suboval to subtriangular depressed areas bounded above by lateral projections of radials (Text-Figs. 3, 4B, 5; Pl. 1, fig. 19). These enclosed areas smaller in BC-and CD-interrays than in remaining interrays (Text-Figs. 3, 4A, B; Pl. 1, fig. 6). Interbrachials irregular polygons, typically five- or sixsided, varying from four- to seven-sided. Largest interbrachials commonly with rounded corners. Interrays displaying poorly developed gradient of progressively smaller plates distally; smaller plates occurring between larger plates throughout interrays (Pl. 1, fig. 3). Interbrachials smooth, without ornamentation, very thin (approximately $0.03 \mathrm{~mm}$ thick), resting on black layer representing degraded organic matter (Text-Figs. 3, 4A; Pl. 1, fig. 5). Interray areas loosely sutured to straight-sided ray series.

Primanal and anitaxis absent. Narrow cylindrical anal

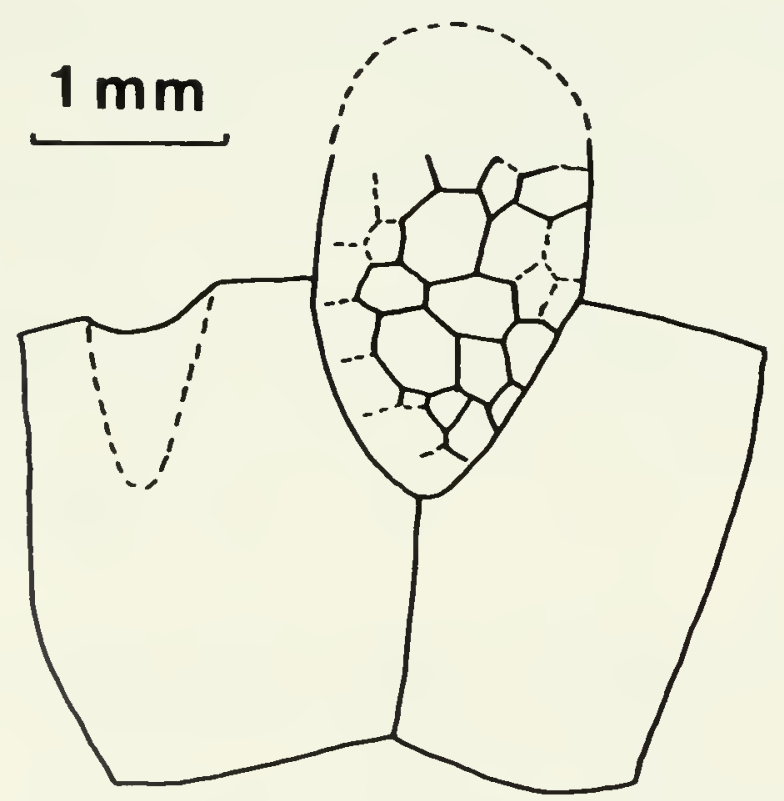

TExT-Fic. 5. Plate diagram of basals and proximal interbrachials in AB-interray of Stipatocrinus hulveri gen. et sp. nov. Paratype RoM 44310b, Pl. 2, fig. 19. tube developed in CD-interray, eccentrically situated near edge of tegmen (Pl. I, figs. 1,11; Pl. 2, figs. 1,9). Anal tube incompletely preserved in available specimens, composed of smooth polygonal plates resembling interbrachials (Text-Fig. 6; Pl. I, figs. 2,4).

Tegmen scen only in cross-section, forming shallow dome consisting of polygonal plates resembling interbrachials in size and shape. Some tegminal plates nodose, commonly bearing short spines (Pl. 1, fig. 12).

Arms ten, pinnulate, relatively long (Table 1). Proximal brachials in uniserial arrangement (Pl. 1, fig. 5), rectangular, wider than high (height/width $=0.4-0.6$ ). Succeeding brachials cuneate, in immature biserial arrangement in distal portions of arms (Pl. 1, fig. 8). Pinnules incompletely known. Pinnulars attached directly to free brachi-

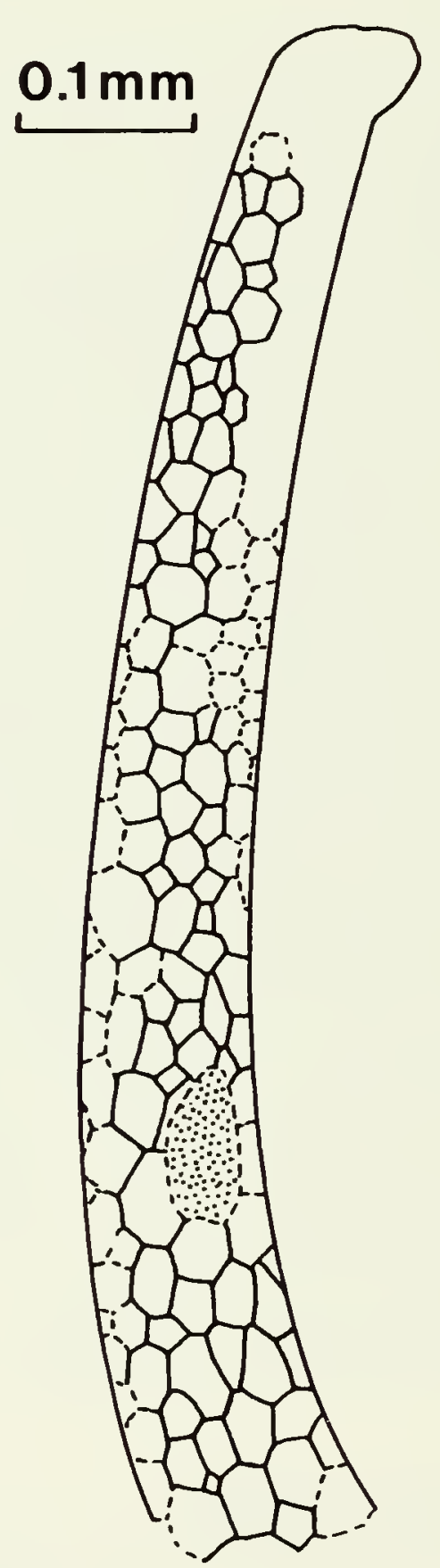

Ti:XT-Fig. 6. Plate diagram of anal tube of Stipatocrinus hulveri gen. et sp. nov. Anal plates resemble interbrachials. Dotted area represents area damaged during preparation. Holotype ROM 44310a, Pl. 1, fig. 2. 
als, short, quadrangular, tapering distally (Pl. 1, fig. 7). Succeeding pinnules lath-shaped (height/width $=2.2-2.7$ ).

Column transversely circular, heteromorphic, tapering uniformly almost to a point distally (PI. 2, figs. 4,5,8,10). Proximal nodals biconcave in longitudinal cross-section with thickened, rounded epifacets concealing adjacent internodals (Text-Fig. 7A, B; Pl. 1, fig. 18). Internodals rectangular or slightly biconvex in longitudinal cross-section.
Proximal columnals thin (nodal height/width $=0.25-0.33$, internodal height/width $=0.06-0.13$ ). Columnals becoming successively thicker in distal portion of column (nodal height $/$ width $=0.28-0.36$, internodal height $/$ width $=0.17$ 0.22 ). Noditaxis typically consisting of one nodal, two or three second-order internodals, a first-order internodal, and two or three second-order internodals (Text-Fig. 7A-D). Lumen small, round (Pl. 2, figs. 6,7).

Table 1. Measurements (in mm) of types of Stipatocrinus hulveri gen. et sp. nov.

Orientation of plate measurements as follows: ROM 44309a-below B-and C-rays (basal), C-ray (radialsecundibrachial); ROM 44309b and 44310a-below C- and D-rays (basal), D-ray (radial-secundibrachial); ROM 44310b-below B- and C-rays (basal), B-ray (radial-secundibrachial).

\begin{tabular}{|c|c|c|c|c|}
\hline Measurements & $\begin{array}{c}\text { Paratype } \\
\text { ROM 44309a }\end{array}$ & $\begin{array}{c}\text { Paratype } \\
\text { ROM } 44309 b\end{array}$ & $\begin{array}{c}\text { Holotype } \\
\text { ROM 44310a }\end{array}$ & $\begin{array}{c}\text { Paratype } \\
\text { ROM } 44310 b\end{array}$ \\
\hline Calyx height & 13.7 & 14.1 & 18.4 & 13.2 \\
\hline Calyx width & $9.1 *$ & $9.2^{*}$ & $10.5^{*}$ & - \\
\hline Arm length & $33.0 \dagger$ & - & - & $18.0^{\dagger}$ \\
\hline Proximal stem diameter & 2.5 & 2.8 & 3.1 & 2.5 \\
\hline Basal height & 2.1 & 1.9 & 2.2 & 2.5 \\
\hline Basal width & 2.1 & 1.9 & 2.5 & 2.5 \\
\hline Radial height & 3.2 & 3.6 & 3.8 & 3.5 \\
\hline Radial width & 2.1 & 2.1 & 2.0 & 2.0 \\
\hline First primibrachial height & 2.8 & 3.6 & 3.8 & 3.2 \\
\hline First primibrachial width & 1.0 & 1.2 & 1.2 & 0.89 \\
\hline Sccond primibrachial height & 2.4 & 2.7 & 2.9 & 2.5 \\
\hline Second primibrachial width & 1.8 & 1.9 & 2.0 & 1.5 \\
\hline Second secundibrachial height & 1.4 & 1.6 & 2.0 & 1.4 \\
\hline Sccond secundibrachial width & 1.0 & 0.97 & 1.0 & 0.81 \\
\hline
\end{tabular}

*Specimen crushed. Actual width less than indicated.

†Dislal portions of arms not preserved.

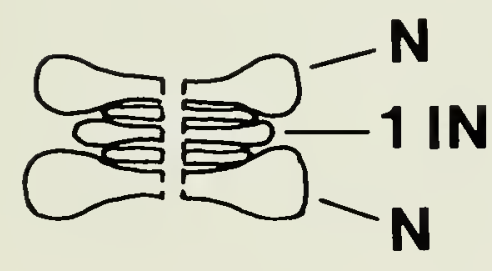

A

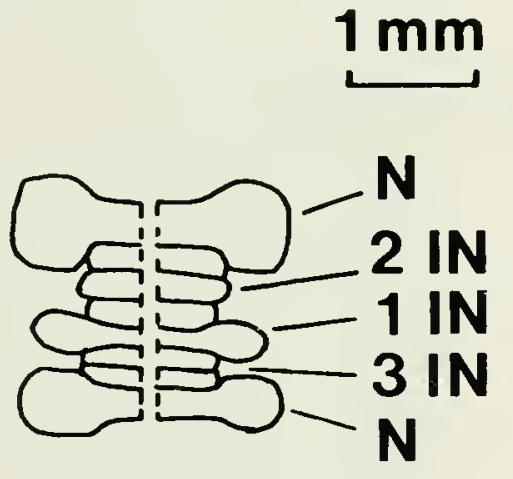

B

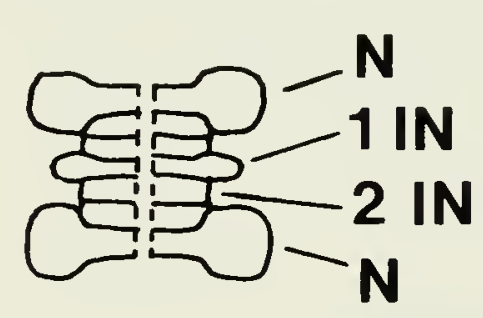

C

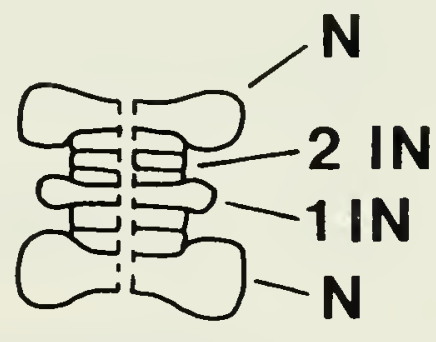

D

TEXT-FIG. 7. Diagrams of longitudinal cross-sections through pluricolumnals of Stipatocrinus hulveri gen. et sp. nov. Nodals and internodals are indicated, respectively, as follows: N, I IN, 2 IN, 3 IN.

A. Pluricolumnal between 9 and $10 \mathrm{~mm}$ below cup of paratype RoM 44319, indicated by upper pair of arrows on PI. 1, fig. 18. Very thin second-order internodals are not visible from exterior of proximal column.

B. Pluricolumnal between 26 and $28 \mathrm{~mm}$ below cup of paratype ROM 44319 , indicated by lower pair of arrows on Pl. 1, fig. 18. Second-order internodal is incipient nodal. Note prominent, thickened epifacets of nodals, which partly enclose adjacent third-order internodals

C. Distal pluricolumnal of paratype RoM 44320, indicated by upper pair of arrows on Pl. 1, fig. 9

D. Distal pluricolumnal of paratype ROM 44320, indicated hy lower pair of arrows on PI. 1, lig. 9. 


\section{Palaeoecology}

Limited lateral extent of slabs bearing Stipatocrinus hulveri on a talus slope in the gorge of the Genesee River and apparent absence of similar slabs in the cliff wall above indicate that these crinoids comprised a highly localized stand, or "garden," on the sealloor. The area of seafloor occupied by this stand, assuming that the majority of specimens have been discovered, did not exceed $0.2 \mathrm{~m}^{2}$. This occurrence represents a high-density stand (sensu Brower, 1973) with about 400 crinoids per square metre. Few fossils, including poorly preserved specimens of the brachiopod Coolinia? and encrusting bryozoans are associated with these crinoids (Pl. 2, fig. 10). The horizon from which the Stipatocrinus material was apparently derived is nearly devoid of fossils, indicating that the sealloor surrounding this stand was sparsely populated by skeletonized benthic organisms. Stands of Early Silurian crinoids described by Brett (1978) and Eckert (1984) also occur in poorly fossiliferous strata. Clustering of conspecific crinoids in these environments may have conferred adaptive advantage by providing viable breeding populations (Brower, 1973).

Polished slabs obtained by sectioning perpendicular to bedding planes reveal that well-preserved Stipatocrinus individuals consisting of nearly complete crowns with long stems occur in calcisiltite adjacent to a thin encrinite (TextFig. 8). Although it is not possible to demonstrate conclusively the sequence of deposition of these layers because the slabs were not recovered in situ, comparison with stands of Early Silurian crinoids excavated in situ (Eckert, 1984) and personal observations of occurrences of well-preserved crinoids in the Middle Devonian Hamilton Group of western New York and Ontario strongly suggest that well-preserved Stipatocrinus individuals are situated immediately above the encrinite. Consisting almost entirely of Stipatocrinus columnals, cup plates, and arm fragments, the encrinite rests with a sharp lower contact on plane-laminated, unfossiliferous calcisiltite. Com-

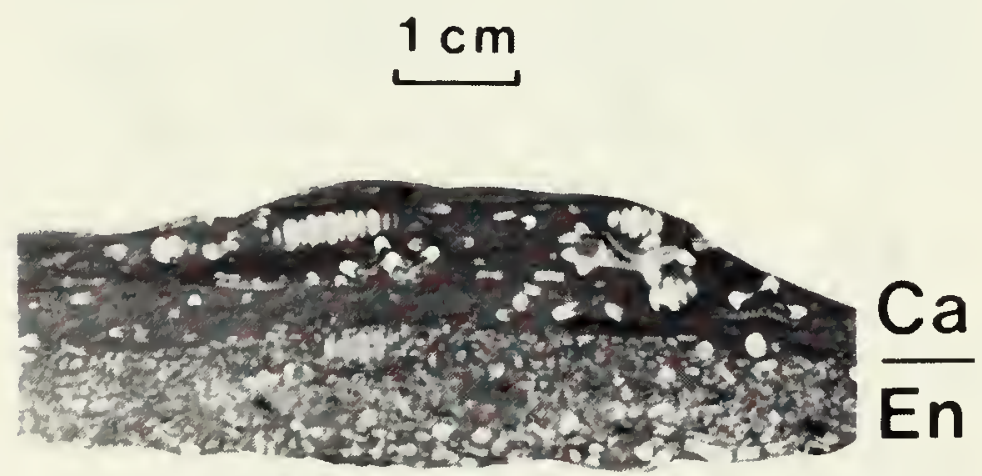

TeXt-Fig 8. Vertical section through slab containing Siipatocrimus hulveri gen. et sp. nov. Basal encrinite (En) is inferred to represent lower surface of slab. Calcisiltite layer $(\mathrm{C} a)$ above encrinite shows well-preserved, sectioned cups and pluricolumnals of S. hulveri. Paratype Rom 44322. plete calyces, typically lacking arms and columns, are embedded in the lower surface of this encrinite.

In reconstructing the palaeoecology of this occurrence, we infer that the Stipatocrinus hulveri stand originated from a chance spatfall on a sparsely populated seafloor. Most of these pioneer individuals attained maturity, as indicated by the large size of radials in the encrinite (PI. 1, fig. 20). Death, decay, and subsequent disarticulation of these crinoids under conditions of generally slow sedimentation gradually formed a carpet of ossicles, represented by encrinite, below the stand. Resuspension of ossicles by currents buried decaying, partly articulated, individuals relatively quickly. Small crinoids, evidently juveniles, associated with larger individuals indicate that the stand survived for more than one generation. Eventually the stand was completely extirpated by rapid burial, indicated by excellent preservation of articulated crinoids in calcisiltite, displaying undulatory laminations. Burial must have been rapid because modern crinoids exposed on the seafloor typically decay and disarticulate quickly after death (Meyer, 1971; Liddell, 1975; Meyer and Meyer, 1986).

In the Reynales Formation at Rochester, beds of Pentamerus, a brachiopod that inhabited relatively shallow, rough-water environments (Boucot, 1975; McKerrow, 1978) alternate with sparsely fossiliferous strata deposited in relatively quiescent, probably deeper water conditions. Thus, occurrence of well-preserved Stipatocrinus specimens in sparsely fossiliferous strata lacking Pentamerus is consistent with a previous interpretation (Brett and Eckert, 1982) that occurrences of well-preserved crinoids are typically associated with quiet-water palaeoenvironments near the limit of normal wave base but within reach of stormgenerated waves and currents. Several slabs bearing $S$. hulveri show prominent, subparallel orientation of crowns and columns suggestive of storm-generated currents during or immediately preceeding burial (Pl. 2, figs. 10,12). After burial the crinoids rapidly decayed, but disarticulation was prevented by overlying sediment and absence of bioturbation. Internal organs were not preserved in any specimens of Stipatocrinus. However, a black carbonaceous film representing degraded organic matter commonly covers inner surfaces of interbrachials (Text-Figs. 3, 4A; Pl. 1, figs. 5,11). A reducing, acidic environment was apparently generated within the calyces as decay proceeded. inducing formation of syngenetic pyrite on some specimens. Acidic conditions caused dissolution of interbrachials in some individuals (Text-Figs. 3, 4A; Pl. 1, figs. $5,11)$. Dissolution probably occurred before lithification because the crinoids are not preserved as steinkerns.

Many Stipatocrinus calyces are filled with sparry calcite. These specimens are typically less crushed or flat- 
tened than individuals filled with calcisiltite. Precipitation of calcite within hollow calyces early in diagenesis may have allowed the crinoids to resist compaction (see Sprinkle and Longman, 1982:69). However, it is also possible that calcite was precipitated late in diagenesis after lithification. When calcite was absent, thinly plated interrays of Stipatocrinus made these crinoids susceptible to compaction, distorting and flattening them.

Densely pinnulate arms and the flexibility of the proximal portion of the column suggest that Stipatocrinus was a rheophilic filter feeder. The t-shaped radials that bridge proximal interray areas helped to strengthen the base of the calyx. However, narrow brachials and unusually thin interbrachials that do not interlock with the ray series made the Stipatocrimus calyx relatively fragile in construction when compared to most other camerates, perhaps restricting this crinoid to relatively low-energy environments. Apparent absence of Stipatocrinus in the Pertumerus community is consistent with this interpretation.

Extremely narrow fixed brachials and $t$-shaped radials made possible incorporation of more interbrachials in Stipatocrinus than any other described crinoid of similar size. Functional morphology of this interray plating is conjectural. The ease with which Stipatocrints calyces were flattened during compaction of the sediment, without breakage of plates, demonstrates that the interrays were flexible in life. Brower (1974a) postulated that large numbers of interbrachials in Xenocrinus aided respiration by diffusion of oxygen through plate sutures, enhanced by pumping action of flexible interrays. Perhaps oxygen could diffuse directly through the unusually thin $(0.03 \mathrm{~mm}$ thick) interbrachials of Stipatocrinus. We note, however, that unlike certain Ordovician crinoids with pore-bearing calyces, there is no evidence of auxiliary respiratory structures in Early Silurian crinoids. Numerous interbrachials in Stipatocrinus may simply be a scaling phenomenon involving thickness/ width ratios of plates: reduction in plate thickness necessitated smaller plate size in order to retain resistance to breakage.

Unusually thin interray plating and a thick but very narrow fixed ray series of the calyx of Stipatocrinus incorporated the smallest amount of calcite possible consistent with requirements for sufficient strength and rigidity. Thus, metabolic cost of calcite secretion in Stipatocrinus was minimal compared to most other thicker-plated crinoids. By reducing metabolic cost, overall growth of Stipatocrinus may well have been rapid, perhaps allowing early reproduction. If Stipatocrintus is assumed to have colonized environments generally unfavourable to most crinoids, as occurred during deposition of the lower Wallington Limestone, an r-selective strategy of early reproduction may have ensured survival.

The column of Stipatocrinus is relatively short, not exceeding $10 \mathrm{~cm}$ in length, and tapers gradually almost to a point distally. Curvature of the distal portion in paratype ROM 44314 (Pl. 2, fig. 8) and in other specimens suggests that the column of Stipatocrinus was coiled distally around other objects for anchorage. This mode of attachment is characteristic of many camerates with gradually tapering, heteromorphic columns, including Alisocrinus, Glyptocrimus, Xenocrinus, and most diplobathrids (Brett, 1981). Possession of a distally coiled column permitted attachment to a wide variety of substrates (Brett, 1985) and was probably a contributing factor in the survival of melocrinitids, glyptocrinids, dimerocrinitids, rhodocrinitids, and the lineage leading to Stipatocrints into the Silurian.

\section{Acknowledgements}

Diligent field work by Michael Hulver resulted in discovery of the study material, and we are indebted to him for making us aware of this occurrence. Additional specimens were collected by Gordon Baird and Karla Parsons. George C. Mclntosh, James Brower, and James Sprinkle critically reviewed the manuscript. Janet Waddington of the De- partment of Invertebrate Palaeontology at the Royal Ontario Museum provided curatorial services. Darkroom and preparation facilities were provided by the Department of Geological Sciences at the University of Rochester. Financial support for this study was provided by the Geological Society of America as grant 3288-84 to Eckert. 



\section{Literature Cited}

AUSICH, W. I.

1985 New crinoids and revision of the superfamily Glyptocrinacca (Early Silurian, Ohio). Journal of Palcontology 59:793-808.

1986a Early Silurian rhodocrinitacean crinoids (Brassficld Formation, Ohio). Journal of Paleontology 60:84-106.

1986b Early Silurian inadunate crinoids (Brassfield Formation, Ohio). Journal of Palcontology 60:719-735.

BERRY, W. B. N. and A. J. BOUCOT

1970 Correlation of the North American Silurian rocks. Geological Socicty of America, Special Paper 102:1-289.

BOUCOT, A. J.

1975 Evolution and extinction rate controls. New York, Elsevier. 427 pp.

BRETT, C. E.

1978 Description and palcoecology of a new Lower Silurian camerate crinoid. Journal of Palcontology 52:91-103.

1981 Terminology and functional morphology of attachment structures in pelmatozoan echinoderms. Lethaia 14:343-370.

1985 Autecology of Silurian pelmatozoan echinoderms. In Bassett, M. G. and J. D. Lawson, eds., Autecology of Silurian organisms. Special Papers in Palacontology 32:87-120.

BRETT, C. E. and J. D. ECKERT

1982 Palaeoecology of a well-preserved crinoid colony from the Silurian Rochester Shale in Ontario. Royal Ontario Museum, Life Sciences Contributions 131:1-20.

BROWER, J. C.

1973 Crinoids from the Girardeau Limestone (Ordovician). Palacontographica Americana 7:259-499.

1974a Upper Ordovician xenocrinids (Crinoidea, Camerata) from Scotland. University of Kansas Paleontological Contributions, Paper 67:1-25.

1974b Ontogeny of camerate crinoids. University of Kansas Paleontological Contributions, Paper 72:1-53.

ECKERT, J. D.

1984 Early Llandovery crinoids and stelleroids from the Cataract Group (Lower Silurian) in southern Ontario, Canada. Royal Ontario Museum, Life Sciences Contributions 137:1-83.

FISHER, D. W.

1960 Correlation of the Silurian rocks in New York State. New York State Museum and Science Service, Geological Survey, Map and Chart Serics 1 .

LIDDELL, W. D.

1975 Recent crinoid biostratinomy. Geological Soeicty of America, Abstracts with Programs 7:1160.

McINTOSH, G. C.

1979 Abnormal specimens of the Middle Devonian crinoid Bactrocrinites and their effect on taxonomy of the genus. Journal of Palcontology $53: 18-28$.

McKERROW, W. S., ed.

1978 The ccology of fossils: an illustrated guide. Cambridge, Mass., MIT Press. 384 pp.

MEYER, D. L.

1971 Post-mortem disarticulation of Recent crinoids and ophiuroids under natural conditions. Geological Society of America, Abstracts with Programs 3:645.

MEYER, D. L. and K. B. MEYER

1986 Biostratinomy of Recent crinoids (Echinodermata) at Lizard Island, Great Barrier Reef, Australia. Palaios 1:294-302.

MILLER, J. S.

1821 A natural history of the Crinoidea or lily-shaped animals, with observation on the genera Asteria, Euryale, Comatula, and Marsupites. Bristol, Bryan. 150 pp.

MOORE, R. C. and L. R. LAUDON

1943 Evolution and classification of Paleozoic crinoids. Geological Society of America, Special Paper 46:1-163.

RICKARD, L. V.

1975 Correlation of the Silurian and Devonian rocks in New York State. New York State Museum, Map and Chart Series 24.

SPRINKLE, J. and M. W. LONGMAN

1982 Echinoderm palcoecology. In Sprinkle J., ed., Echinoderm faunas of the Bromide Formation (Middle Ordovician) of Oklahoma. University of Kansas Paleontological Contributions, Monograph 1:67-75.

UBAGHS, G.

1978 Skeletal morphology of fossil crinoids. In Moore, R. C. and C. Teichert, eds., Treatise on invertebrate palcontology, part T, Echinodermata 2. Lawrence, Geological Society of Amcrica and University of Kansas Press, pp. 59-216.

WACHSMUTH, $\mathrm{C}$. and F. SPRINGER

1885 Revision of the Palacocrinoidea. Proceedings of the Academy of Natural Seiences of Philadelphia for 1885:225-364.

WARN, J. M.

1975 Monocyclism vs. dicyclism: a primary schism in crinoid p'. ylogeny? Bulletins of American Paleontology 67:423-441.

WITZKE, B. J., T. J. FREST, and H. L. STRIMPLE

1979 Biogeography of the Silurian-Devonian echinoderms. In Gray, J. and A. J. Boucot, eds., Historical biogeography, plate tectonics, and the changing environment. Corvallis, Oregon State University Press, pp. 117-129.

WITZKE, B. J. and H. L. STRIMPLE

1981 Early Silurian camerate crinoids of eastern lowal. lowa Academy of Science. Proceedings 88:101137. 
Plate 1, figs. 1-21,

Stipatocrimus hulveri gen. et sp. nov. Reynales Formation, Rochester, New York. Specimens immersed in ethanol.

1. CD-interray of well-preserved individual. Note absence of primanal and anitaxis. Proximal circlet is divided by suture in DE-interray but not in CD-interray; $t$-shaped radials bridge proximal interray areas. enclosing interbrachials between basals and lateral projections of radials. Narrow, highly raised brachials enclose thinly plated interrays consisting of numerous, polygonal interbrachials. Distal interbrachials merge with plates of anal tube and tegmen without differentiation. See also Text-Fig. 6; PI. I, figs. 2-4, 10; PI. 2, lig. 1. Holotype Rom 44310a, $\times 3.5$.

2. Cylindrical anal tube of above individual showing arrangement of irregular polygonal plates. Distal portion of tube is missing. See Text-Fig. 6 for a diagram of this specimen. Holotype rom 44310a, $\times 8.0$.

3. CD-interray detail between lirst primibrachial and second secundibrachial. Interray, slightly separated from C-ray in this individual, is composed of numerous polygonal interbrachials irregular in shape and arrangement. Holotype ROM 44310a, $\times 7.0$.

4. C-ray and adjoining interbrachials showing proximal portion of anal tube and lirst pinnular of fixed pinnule borne by second secundibrachial. Holotype RoM $44310 \mathrm{a}, \times 7.0$.

5. Anterior view of nearly complete crown. Orientation of rays unknown. Interbrachials, apparently dissolved during diagenesis, are absent in most of interray area, revealing underlying black layer representing degraded organic matter. Interray areas below lateral projections of radials are subtriangular in this specimen. Proximal free brachials are uniserial. See also Pl. 2, fig. 12. Paratype Rom 44311f, $\times 3.0$.

6. Specimen centred on B-ray. Numerous irregular polygonal interbrachials are visible in BC-interray. Basal circlet is divided by suture in AB-interray but not in BC-interray. See also Text-Fig. 5; PI. 1, fig. 19; Pl. 2, fig. 3. Paratype RoM 44310b, $\times 4.0$.

7. Proximal arm detail. Note short pinnules. Paratype rom 44321, $\times 5.0$.

8. Distal portion of arm with cuneate brachials. Paratype ROM 44309d, $\times 5.0$.

9. Longitudinal cross-section through distal column. Nodals have prominent, thickened epifacets. Typical noditaxis consists, sequentially, of a nodal, two or three second-order internodals, a first-order internodal, and two or three second-order internodals. See Text-Fig. 7C,D for diagrams of two noditaxes indicated here by pairs of arrows. Paratype Rom $44320, \times 4.0$.

10. Intersecundibrachial detail between bifurcation of D-ray. Holotype Rom $44310 \mathrm{a}, \times 6.0$.

11. CD-interray of crown. Incomplete anal tube is outlined by black integument. Most interbrachials are missing. See also PI. 2, fig. 12. Paratype ком $44311 \mathrm{a}, \times 2.0$.

12. Longitudinal cross-section through distal fixed secundibrachials and tegmen. Many tegminal plates possess nodes or short spines. Paratype ROM 44315, $\times 6.0$.

Figs. 13-16. Sequential series of cross-sections through lower portion of cup destroyed by progressive grinding. C-ray is at upper left of each section.

13. Basals just above stem. Note small opening for lumen. Basal suture at upper left is directly below C-ray. Two basals below B-, C-, and D-rays are larger than remaining basals.

14. Slightly higher section through basals showing initial development of ridges on rays.

15. Basals sectioned near top of eup with prominent ridges on rays.

16. Section through proximal portions of radials and interrays. Each radial has prominent ventral groove.

17. Cup transversely sectioned just below bifurcation of rays. Cup has been strongly compressed, demonstrating flexibility of thinly plated interrays. Paratype ROM 44316, × 3.0.

18. Longitudinal cross-section through column and proximal portion of cup. One basal and part of adjoining radial are visible. Proximal nodals are transversely biconcave with slightly thickened epifacets. Internodals are typically transversely biconvex. See Text-Fig. 7A,B for diagrams of two noditaxes indicated here by pairs of arrows. Paratype Rom 44319, $\times 3.0$.

19. Proximal AB-interray area enclosed by basals and lateral projections of t-shaped radials. Numerous irregular, polygonal interbrachials are visible. See Text-Fig. 5 for a diagram of this specimen. Paratype RoM $44310 \mathrm{~b}, \times 10.0$.

20. Isolated radial showing characteristic lateral projections and deep ventral groove. Left projection is incomplete. Paratype ROM 44323, × 5.0.

21. Transverse cross-section through three calyces, each sectioned near bifurcation of rays. Fixed brachials contain prominent ventral groove. Paratype RoM 44313, $\times 3.0$. 

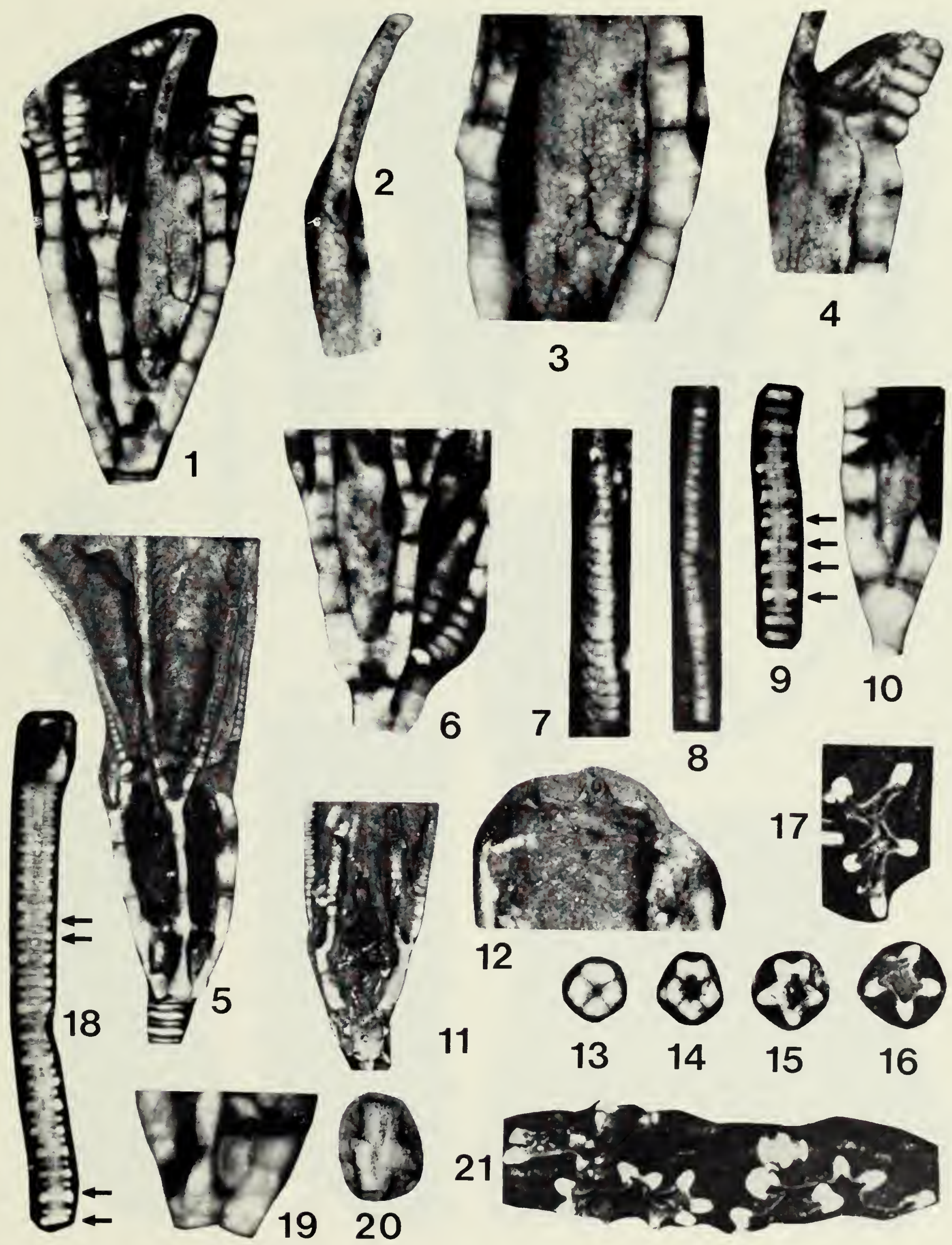
Plate 2, figs. 1-12.

Stipatocrinus hulveri gen. et sp. nov. Reynales Formation, Rochester, New York. Blackened specimens whitened with ammonium chloride.

1. CD-interray of holotype specimen. Suboval interbrachial area in CD-interray, bounded by a single basal and $\mathrm{t}$-shaped radials of $\mathrm{C}$ - and D-rays, is smaller than adjacent area in DE-interray, bounded below by two basals. See also Text-Fig. 6; PI. 1, figs. 1-4,10. ком 44310a, $\times 3.5$.

2. Lateral view of nearly complete crown centred on B-ray. See also Pl. 2, fig. 12. Paratype Rom 44311 , $\times 1.5$.

3. Crown centred on B-ray. Suboval interbrachial area of proximal AB-interray is larger than adjacent suboval area in BC-interray. See also Text-Fig. 5; Pl. 1, figs. 6,19. Paratype ком $44310 \mathrm{~b}, \times 2.8$.

4. Partial crown centred on C-ray. Proximal bifurcation of C-ray ridge continues on basals. See also PI. 2, fig. 12. Paratype RoM $4431 \mathrm{lb}, \times 2.8$.

5. CD-interray view of crown with most of column. See also Pl. 2, fig. 12. Paratype Rom 44311 e, $\times 2.0$.

6. Pluricolumnal. Two internodals are attached to nodal with prominent epifacet. Paratype ROM $44318 \mathrm{~b}$, $\times 7.0$.

7. Pluricolumnal. Intemodal is attached to nodal displaying broad epifacet. Note small lumen. Paratype ROM $44317 \mathrm{a}, \times 7.0$.

8. Incomplete column coiled distally. Paratype ROM 44314, $\times 2.0$.

9. CD-interray of individual with proximal portion of anal tube. See also Pl. 2, fig. 12. Paratype ROM $44311 \mathrm{a}, \times 3.0$.

10. Small slab with nearly complete crown and column near centre of photograph, two additional partial crowns and numerous pluricolumnals. These small specimens represent juvenile crinoids. Paratypes ROM $44312 \mathrm{a}-\mathrm{c}, \times 0.8$

11. Detail of above slab. Lower crown possesses two essentially complete arms. Paratypes Rom 44312a-c, $\times 1.6$.

12. Well-preserved crinoids on small slab. Specimens are oriented subparallel to each other, suggesting unidirectional current at time of burial. Paratypes ROM $44311 \mathrm{a}-\mathrm{i}, \times 0.8$. 


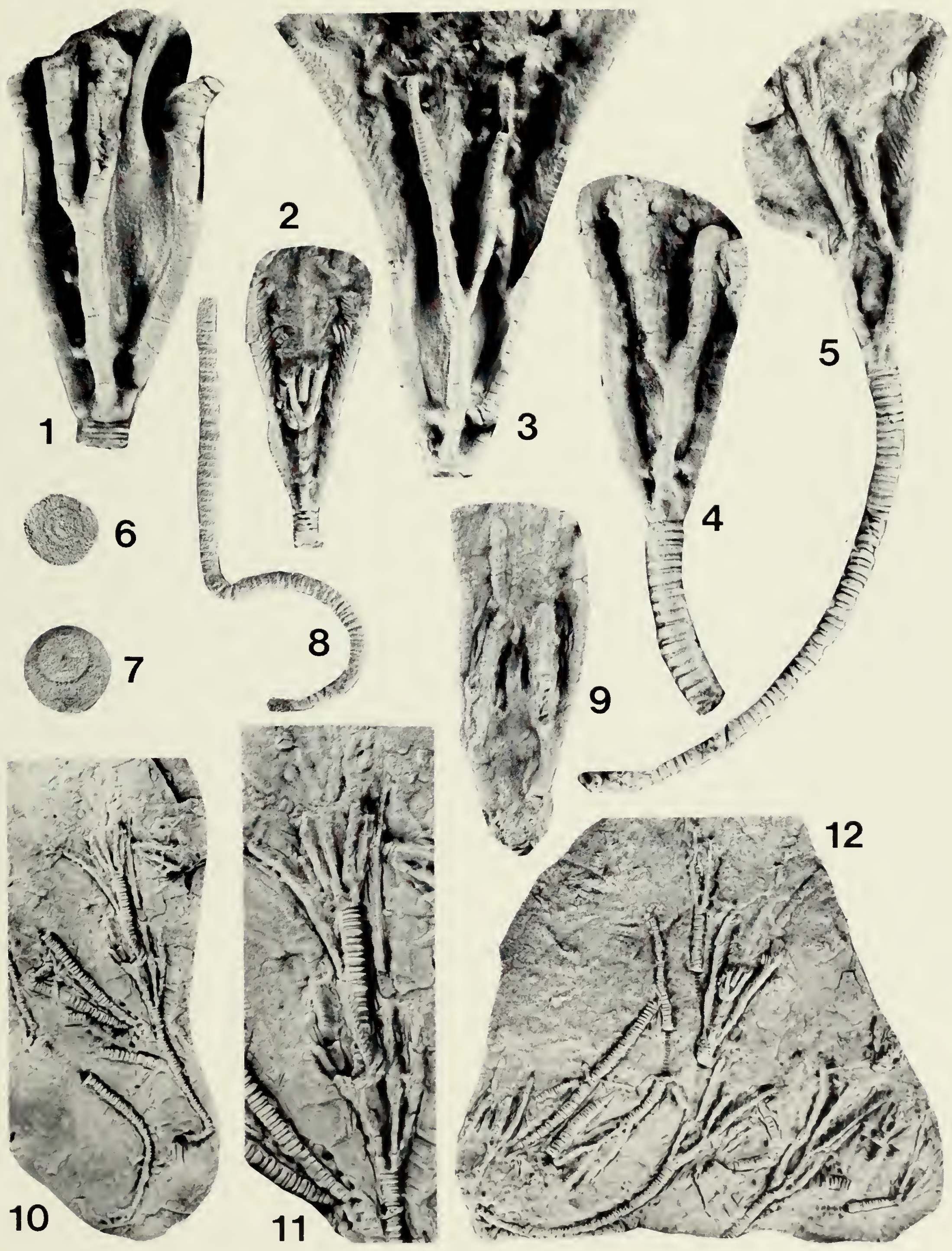






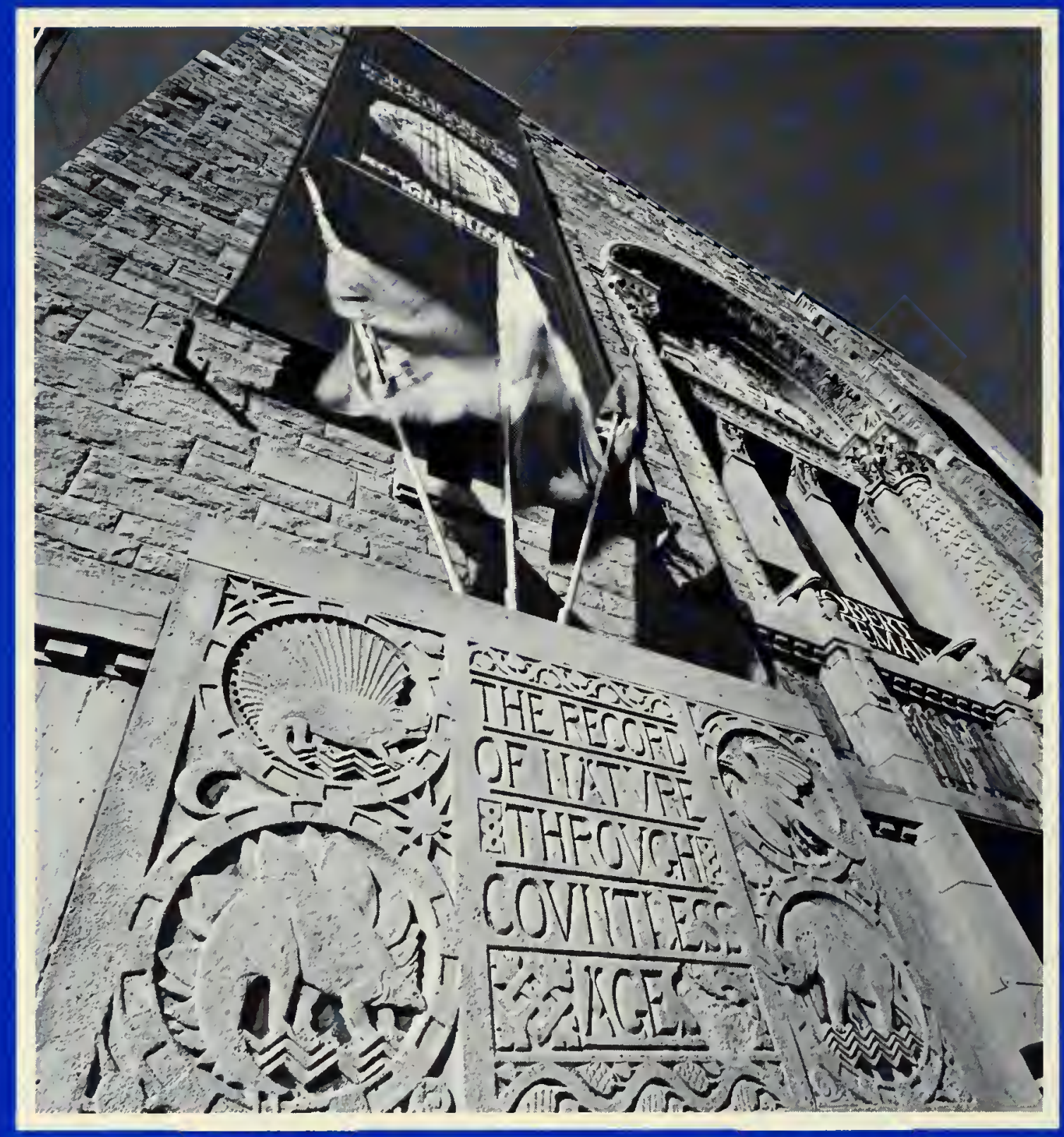

ISBN 0-88854-336-0

ISSN 0384-8159 